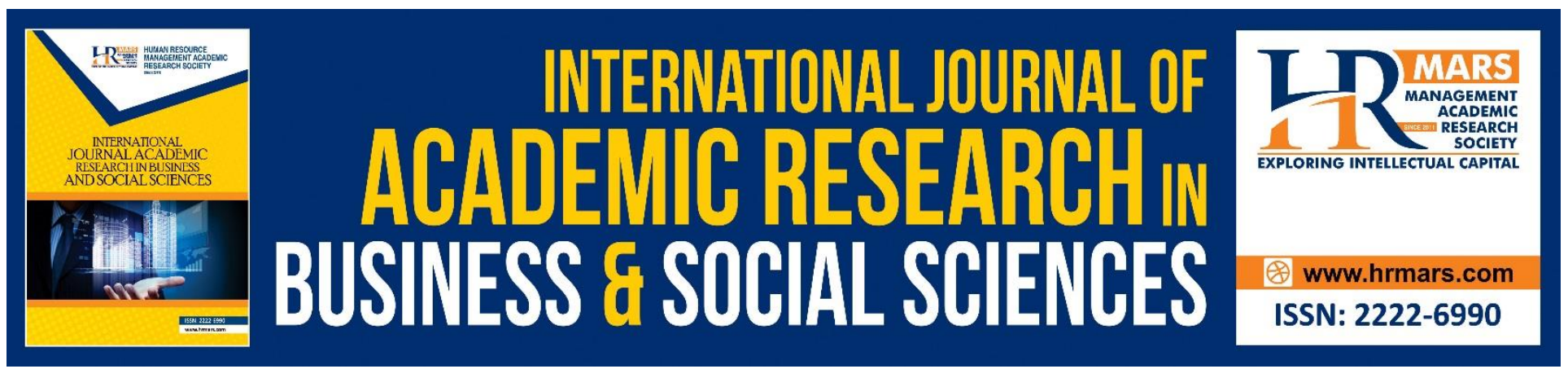

\title{
Psychometric Assessment Using the Differentiation in The Family System Scale (DIFS) Among Ethnic Chinese Adults in Selangor
}

Teoh Wan Yee, Suzana Mohd Hoesni, Nor Ba'yah Abdul Kadir, Dan Zainah Ahmad Zamani

To Link this Article: http://dx.doi.org/10.6007/IJARBSS/v10-i10/7922

DOI:10.6007/IJARBSS/v10-i10/7922

Received: 20 July 2020, Revised: 19 August 2020, Accepted: 11 September 2020

Published Online: 10 October 2020

In-Text Citation: (Yee, Hoesni, Abdul Kadir, \& Zamani, 2020)

To Cite this Article: Yee, T. W., Hoesni, S. M., Abdul Kadir, N. B., \& Zamani, D. Z. A. (2020). Family System Scale (DIFS) Among Ethnic Chinese Adults in Selangor. International Journal of Academic Research in Business and Social Sciences. 10(10), 120-133.

\section{Copyright: (c) 2020 The Author(s)}

Published by Human Resource Management Academic Research Society (www.hrmars.com)

This article is published under the Creative Commons Attribution (CC BY 4.0) license. Anyone may reproduce, distribute, translate and create derivative works of this article (for both commercial and non-commercial purposes), subject to full attribution to the original publication and authors. The full terms of this license may be seen

at: http://creativecommons.org/licences/by/4.0/legalcode

Vol. 10, No. 10, 2020, Pg. 120 - 133

http://hrmars.com/index.php/pages/detail/IJARBSS

JOURNAL HOMEPAGE

Full Terms \& Conditions of access and use can be found at http://hrmars.com/index.php/pages/detail/publication-ethics 


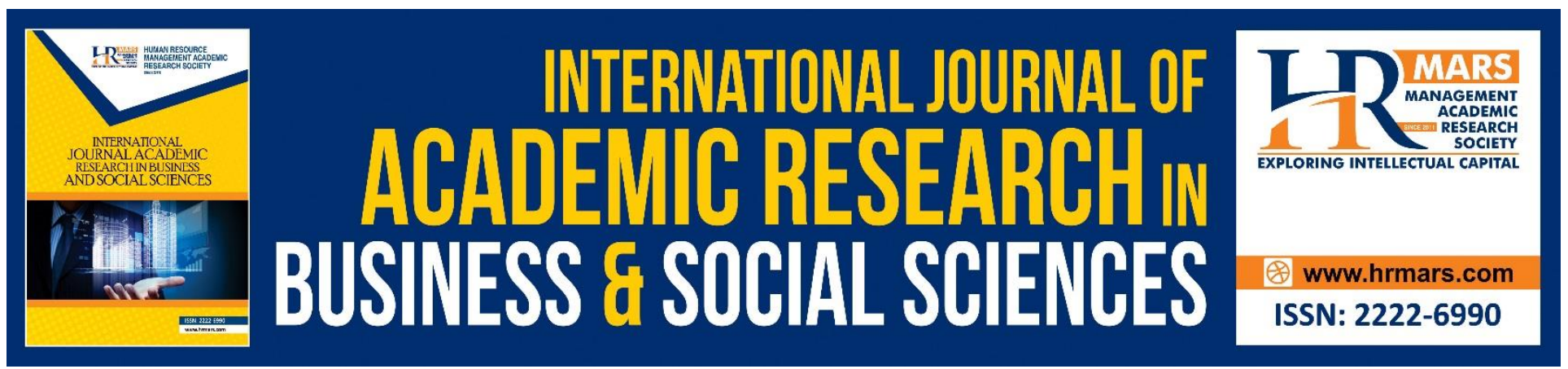

\title{
Psychometric Assessment Using the Differentiation in The Family System Scale (DIFS) Among Ethnic Chinese Adults in Selangor
}

\section{Teoh Wan Yee, Suzana Mohd Hoesni, Nor Ba'yah Abdul Kadir, Dan Zainah Ahmad Zamani}

Psychology and Human Well-Being Research Centre, Faculty of Social Sciences and Humanities, Universiti Kebangsaan Malaysia, Bangi, Selangor.

Email: huanyi19@gmail.com, smh@ukm.my, aknbayah@ukm.edu.my,Zainah@ukm.edu.my

\begin{abstract}
The purpose of this study was to evaluate the psychometrics of The Differentiation in the Family System Scale (DIFS) in terms of internal consistency reliability using Cronbach's alpha and construct validity measured through factor analysis. The sample in this study consisted of 384 ethnic Chinese in Malaysia living in Selangor. The findings of the study showed that DIFS has a very good reliability index $(\alpha=.900)$. The findings also show that this scale is reliable and valid. This study only focused on 17 items involving the subscales "interaction between mother and me" and "interaction between father and me" subscales. All DIFS items also perform as a self-differentiating factor. Looking forward, it is recommended that future researchers expand and explore the study further by evaluating family resources in terms of various aspects of relationships. The findings of the study show that The Differentiation In The Family System Scale (DIFS) psychometric are suitable for the local culture and environment based on its capability of producing reliable test results.
\end{abstract}

Keywords: Differentiation of Self, Psychometric, Family System, Adulthood Psychology, Malaysian Ethnic Chinese.

\section{Introduction}

There are various terminologies used by researchers to describe the concept of family. The family is a dynamic institution and each of its members is interconnected and influences each other in an area (Azizi, 2008; Zhou, 2020). According to Hellinger (2014), family dynamics can be observed through the children. This situation will be influenced and passed on from a generation to another generation in the family system. Multigenerational theory by Bowen (1978) stated a predictive factor with self-differentiation, also known as "the differentiation of self". This factor is a self-adaptive ability by showing the extent to which a person thinks and acts in a relationship by experiencing various emotions (Lampis, 2015; Lampis, Cataudella, Agus, Busonera, \& Skowron, 2018). 
INTERNATIONAL JOURNAL OF ACADEMIC RESEARCH IN BUSINESS AND SOCIAL SCIENCES Vol. 10, No. 10, 2020, E-ISSN: 2222-6990 @ 2020 HRMARS

Therefore, differentiation is conceptualized as a family-level variable involving interactions that allow individuals to maintain both feelings namely a sense of emotional connection (support, involvement, personal relationship) and a sense of isolation (autonomy, uniqueness, freedom of expression) (Anderson \& Sabatelli, 1992). This aspect focuses on key aspects of life experience in the roots of the family-of-origin, quantitatively using questionnaire measures to assess differentiation in the family as well as the process of how adult individuals differentiate themselves from the familyof-origin and interact with parents (Holman \& Birch, 2001).

According to Bowen (1978), individuals act by referring to the extent of the difference in response between thoughts and feelings from the family-of-origin. This condition also indicates that the family has a stimulating effect on the individual and leaves an impact on the physical and psychological development of an individual as an adult. This statement has been supported by the results of studies conducted locally and abroad that have found this theory to be universal and the differentiation of self is an important factor in overcoming one's psychological well-being in different cultures (Bowen, 1978; Kerr \& Bowen, 1988; Holman \& Birch, 2002; Chung \& Gale, 2006, Timm \& Keiley, 2011; Raba'aton Adawiah, 2011; Norfaezah, 2016; Lee \& Sabatelli, 2018; Peleg \& Messerschmidt, 2018).

The Differentiation In The Family System Scale (DIFS) is considered a good instrument for measuring the differentiation of self in the family-of-origin by referring to Bowen's multigenerational theory (1978). The items found in DIFS are sufficient to ensure consistency in reliability. This statement is also supported in various research results that record satisfactory levels of reliability and validity (Gavazzi, 1994; Sabatelli and Bartle, 2003; Li, 2011; Muraru, \& Turliuc, 2012; 2013).

In general, this study aims to evaluate the psychometric aspects of The Differentiation In The Family System Scale (DIFS) instrument, which includes the reliability of internal consistency and construct validity of the Malaysian ethnic Chinese sample. Reber (1985) explained that reliability testing is very important in a study that employs a questionnaire because of its ability to test and analyse using alpha coefficients to measure variables in research. Wiersma (2000) added instrument reliability is a measurement value to determine the consistency of the score of each item. Whereas Campbell and Fiske (1959) described validity as an agreement between two attempts to measure the same trait to the maximum through different methods.

Specifically, there are two objectives in this study namely, first, to identify the level of reliability of DIFS internal consistency and second, to determine the validity of the DIFS construct.

\section{The Methodology of the Study Study Design}

This study is in the form of a survey using a questionnaire. It aims to determine the level of reliability and validity of The Differentiation In The Family System Scale (DIFS) instrument from a sample of Malaysian ethnic Chinese living around Selangor. The reliability of the instrument is assessed from the aspect of internal consistency while the validity of the instrument is evaluated from the aspect of construct validity. 
INTERNATIONAL JOURNAL OF ACADEMIC RESEARCH IN BUSINESS AND SOCIAL SCIENCES Vol. 10 , No. 10, 2020, E-ISSN: 2222-6990 @ 2020 HRMARS

\section{Sample and Location of the Study}

A total of 384 Malaysian ethnic Chinese in the age group of 25 to 44 years who lived around Selangor participated in this study. Samples were selected through objective sampling.

\section{Study Tools}

A set of the questionnaire consists of three parts, namely:

Personal Details Form. It includes demographic items such as gender, age, family hierarchy, level of education, employment, parents' marital status, years of marriage and the number of children.

Differentiation of Self. The Differentiation In The Family System Scale (DIFS) instrument was developed by Anderson \& Sabatelli (1992). Differentiation of self sample was measured using the Chinese version of DIFS produced through translation by Wang (1996) from Taiwan. Originally, the DIFS scale contained 11 items with a circular questioning format to assess individual perceptions of how family members interacted. In this study, the researcher only considers 17 items that involved the "interaction between parents and me" relationship that is the "interaction between mother and me" subscale of 9 items and "interaction between father and me" subscale of 8 items. Table 1 presents the aspects of the relationship and the item numbers.

Table 1

The Differentiation In The Family System Scale (DIFS) Subscale

\begin{tabular}{|c|c|c|}
\hline Subscale & Item Numbers & Total \\
\hline Interaction Between Mother and Me & $\begin{array}{l}\text { C1a, C2a, C3a, C4a, C5a, C6a, } \\
\text { C7a, C8a, C9a }\end{array}$ & 9 \\
\hline Interaction Between Father and Me & $\begin{array}{l}\text { C1b, C2b, C3b, C4b, C5b, } \\
\mathrm{C} 6 \mathrm{~b}, \mathrm{C7b}, \mathrm{c} 8 \mathrm{~b}\end{array}$ & 8 \\
\hline Number of Items & & 17 \\
\hline
\end{tabular}

The DIFS scale used is a five-point Likert scale consisted of (1) Very Infrequent; (2) Infrequent; (3) Sometimes; (4) Frequent; and (5) Very Frequent. In terms of scoring the DIFS test tool, the scoring technique is to sum up the overall score for the differentiation of self from the family-of-origin. A high number of scores indicates that the sample has a high level of self-differentiation while a low score indicates that the level of self-differentiation of the sample is low. Table 2 below displays the positive and negative items in the DIFS. 
INTERNATIONAL JOURNAL OF ACADEMIC RESEARCH IN BUSINESS AND SOCIAL SCIENCES

Vol. 10, No. 10, 2020, E-ISSN: 2222-6990 @ 2020 HRMARS

Table 2

Positive and Negative Items in The Differentiation In The Family System Scale (DIFS) Psychometric

\begin{tabular}{|c|c|c|}
\hline Item Types & Item Numbers & Total \\
\hline \multicolumn{3}{|c|}{ Interaction Between Mother And Me } \\
\hline Positive & C1a, C3a, C4a, C6a, C8a, C9a & \\
\hline Negative & $\mathrm{C} 2 \mathrm{a}, \mathrm{C5a}, \mathrm{C7a}$ & \\
\hline \multicolumn{3}{|c|}{ Interaction Between Father And Me } \\
\hline Positive & $c 1 b, c 3 b, c 4 b, C 5 b, C 7 b, c 8 b$ & \\
\hline Negative & $\mathrm{c} 2 \mathrm{~b}, \mathrm{C} 6 \mathrm{~b}$ & 2 \\
\hline
\end{tabular}

\section{The Analysis}

Internal consistency reliability was measured using the Cronbach's alpha coefficient and construct validity was measured using factor analysis. Validity means the extent to which an instrument to be used can test what is supposed to be tested. Or the extent to which the stated indicators have or can fit the item construct (Ghazali Darusalam and Sufean Hussin, 2018). Validating the construct through factor analysis and the questionnaire instrument in the quantitative study were conducting using Confirmatory Factor Analysis (CFA) technique.

CFA (Confirmatory Factor Analysis) was used to isolate overlapping in their factor/construct, with a factor loading of $r=>.500$ (Hair, Black, Babin, \& Anderson, 2010). CFA is used for testing the validity of modified instruments or taken from existing instruments, and existing items have been determined according to their constructs. Factor analysis was performed to determine the level of validity of item constructs in a set of instruments which was also performed with the objective of arranging a large number of questionnaire items into specific constructs under study variables to identify and reduce the suitability of items in their constructs.

The researchers have divided the results of the CFA analysis for each construct and report the results of the analysis in detail so they can be examined and brought for the differentiation of self construct. Study data were analysed using SPSS for Windows software.

\section{The Findings}

\section{Sample Background}

Based on the descriptive analysis, the study showed the whole sample $(\mathrm{N}=384)$. In terms of gender, a total of 303 individuals (78.9\%) consisted of females and 81 males (21.1\%). In regards to the sample in the study that have been married according to their age groups, the results showed that most of them or 172 individuals (44.8\%) consisted of those who were between 40 to 44 years old, while 125 individuals (32.6\%) were between 35 to 39 years old, 51 individuals (13.3\%) were between 30 to 34 years old, and the smallest group of 36 individuals (9.4\%) were between 25 to 29 years old.

The findings of the study according to family hierarchy show that the majority of the sample population or 164 respondents (42.7\%) are neither firstborns nor the youngest as compared to 133 
INTERNATIONAL JOURNAL OF ACADEMIC RESEARCH IN BUSINESS AND SOCIAL SCIENCES Vol. 10, No. 10, 2020, E-ISSN: 2222-6990 @ 2020 HRMARS

respondents (34.6\%) being the eldest, while 8 of them (22.7\%) are the youngest. From the findings of the study, it is also shown that in terms of the level of education, the majority or 54.2 percent (208) of adult children have bachelor's degrees, while 19.8 percent (76) have diplomas, 9.4 percent (36) have master's degrees, 8.1 percent (31) have SPM, 5.2 percent (20) have STPM, 1.8 percent (7) have SRP/PMR, 0.8 percent (3) completed primary school, and the same percentage of 0.8 percent (3) have PhDs.

When categorised according to employment, the findings of the study show that the majority of the, which is about 89.3 percent (343) are working couples, while 10.7 percent (41) are unemployed couples. In terms of parents' marital status, the highest majority of 65.1 percent (250) have parents who are married and living together, while 24.0 per cent (92) have single parents or either one of their parents deceased, 5.2 per cent (20) mentioned other categories in regards to the marital status of their parents, 3.4 percent (13) have parents who are married but living separately and finally, 2.3 percent of the sample population (9) stated their parents are divorcees.

Findings of the study in terms of the distribution of married individuals in the sample population are categorised according to years of marriage. The findings of the study suggest that the highest majority that is about 31.0 percent (119) have been married between 6 to 10 years, while 27.1 percent (104) have been married between 11 to 15 years, 25.5 percent (98) have been married between 1 to 5 years, 8.3 percent (32) have been married between 21 to 25 years, and a small percentage of 8.1 percent (31) have been married between 16 to 20 years.

Finally, in terms of the number of children, the findings show that the majority of the couples or 57.3 percent (220) have 1 to 2 children, while 22.1 percent (85) of the couples have 3 to 4 children, 19.5 percent (75) of the couples do not have any child and only 1.0 percent of the (4) couples have more than 5 children.

\section{The Differentiation In The Family System Scale (DIFS) Psychometric}

Table 3 below displays a mean comparison of 9 items in The Differentiation In The Family System Scale (DIFS) instrument for the "interaction between mother and me" subscale. It has been found that item C3a which is ".... Will respect (my) privacy" recorded the highest mean of 4.04 followed by item C2a that is "... .treat (my) feelings as nothing" recorded a mean of 3.80; item C7a that is. "... treat (my) point of view and opinion as nothing" recorded a mean of 3.76; item C9a that is. "... able to tolerate (me) to defend (my) own point of view/idea" recorded a mean of 3.64; item C1a with the statement "....will respect (my) point of view even (our) points of view are different" recorded a mean 3.63; the next item C5a that is "... there is a lack of concern to (my) feelings" recorded a mean of 3.54; item C8a with the statement "... shows understanding when (I) do not want to share (my) feelings" recorded a mean of 3.53 followed by item C4a which is "...accept my feelings in an understanding way" recorded a mean of 3.48 and finally item C6a that is "...will encourage (me) to express (my) inner positive or negative feelings" recorded the lowest mean of 3.00. The mean for the "interaction between mother and me" subscale for DIFS that includes 9 items is recorded at 32.42 . 
INTERNATIONAL JOURNAL OF ACADEMIC RESEARCH IN BUSINESS AND SOCIAL SCIENCES Vol. 10, No. 10, 2020, E-ISSN: 2222-6990 @ 2020 HRMARS

\section{Table 3}

Mean Differences For Interaction Between Mother And Me Subscale Items

\begin{tabular}{ccc}
\hline Item & Mean & Standard Deviation \\
\hline C1a & 3.63 & 0.94 \\
C2a & 3.80 & 1.01 \\
C3a & 4.04 & 0.88 \\
C4a & 3.48 & 1.04 \\
C5a & 3.54 & 1.13 \\
C6a & 3.00 & 1.18 \\
C7a & 3.76 & 1.01 \\
C8a & 3.53 & 1.06 \\
C9a & 3.64 & 0.98 \\
\hline Scale & 32.42 & 9.23 \\
(9Items) & & \\
\hline
\end{tabular}

Table 4 below shows the mean comparison of the 8 items in The Differentiation In The Family System Scale (DIFS) instrument for the "interaction between father and me" subscale. It has been found that item $\mathrm{C} 2 \mathrm{~b}$ which is "....treat (my) feelings as nothing" recorded the highest mean of 3.98 followed by item C3b which is "...will respect (my) privacy" recorded a mean of 3.88; item C6b namely "...treat (my) point of view and opinion as nothing" recorded a mean of 3.82; item C1b i.e. "...will respect (my) point of view even (our) points of view are different" recorded a mean of 3.72; item C8b with the statement "...able to tolerate (me) to defend (my) own point of view/idea" recorded a mean of 3.68; the next item C4b which is "...accept my feelings in an understanding way" recorded a mean of 3.61 and followed by item C7b with the statement "...shows understanding when (I) do not want to share (my) feelings" recorded a mean of 3.61 and finally, item C5b namely "...will encourage (me) to express (my) inner positive or negative feelings" recorded the lowest mean of 3.19. The mean for the "interaction between father and me" subscale for DIFS which includes 8 items is recorded at 29.49.

Table 4

Mean Differences For Interaction Between Father And Me Subscale

\begin{tabular}{ccc}
\hline Item & Mean & Standard Deviation \\
\hline C1b & 3.72 & 0.95 \\
C2b & 3.98 & 0.96 \\
C3b & 3.88 & 1.00 \\
C4b & 3.61 & 1.04 \\
C5b & 3.19 & 1.18 \\
C6b & 3.82 & 1.04 \\
C7b & 3.61 & 1.06 \\
C8b & 3.68 & 0.99 \\
\hline Scale & 29.49 & 8.22 \\
(8Items) & & \\
\hline
\end{tabular}


INTERNATIONAL JOURNAL OF ACADEMIC RESEARCH IN BUSINESS AND SOCIAL SCIENCES Vol. 10 , No. 10, 2020, E-ISSN: 2222-6990 @ 2020 HRMARS

\section{The Reliability and Validity of The Differentiation In The Family System Scale (DIFS)}

An analysis of the reliability of internal consistency using the Cronbach's alpha method showed that the DIFS instrument has an excellent level of internal consistency reliability $(\alpha=.900)$, as described by Vierra \& Pollock (1992). Although it recorded excellent internal consistency reliability, item $\mathrm{C} 5 \mathrm{a}$ in this study was found not to contribute effectively to DIFS internal consistency. If item C5a is removed, the value of the Cronbach's alpha coefficient increases from 0.900 to 0.901 . Table 5 points out the Cronbach's alpha coefficient for the DIFS instrument.

Table 5

DIFS Cronbach's Alpha Coeffecient

\begin{tabular}{ccc}
\hline DIFS & $\begin{array}{c}\text { Corrected Item- Total } \\
\text { Correlation }\end{array}$ & $\begin{array}{c}\text { Alpha if Item } \\
\text { Deleted }\end{array}$ \\
\hline C1a & 0.527 & 0.896 \\
C2a & 0.527 & 0.896 \\
C3a & 0.445 & 0.898 \\
C4a & 0.590 & 0.894 \\
C5a & 0.386 & 0.901 \\
C6a & 0.555 & 0.895 \\
C7a & 0.571 & 0.894 \\
C8a & 0.600 & 0.893 \\
C9a & 0.623 & 0.893 \\
C1b & 0.621 & 0.893 \\
C2b & 0.492 & 0.897 \\
C3b & 0.562 & 0.895 \\
C4b & 0.627 & 0.893 \\
C5b & 0.603 & 0.893 \\
C6b & 0.525 & 0.896 \\
C7b & 0.637 & 0.892 \\
C8b & 0.619 & 0.893 \\
\hline
\end{tabular}

From the evaluation of DIFS validity using the factor analysis method, the findings of the study showed that DIFS items are correlated with the overall score of the DIFS scale. It also meets the general criteria that have been stated namely, KMO test value and Bartlett's Test, that shows the $\mathrm{KMO}$ value generated that is 0.817 , is greater than 0.50 . This $\mathrm{KMO}$ value explains that the data does not have multicollinearity issue (item $>.900$ ) and the item is suitable to perform factor analysis. Bartlett's Test of Sphericity test showed a value of $k<0.05$, which is a significant result and the correlation between items is sufficient to conduct factor analysis.

The value for Bartlett's Test of Sphericity, Approx. Chi-Square is large and significant where $\mathrm{X}^{2}$ $=4377.482, \mathrm{df}=231, \mathrm{sig}=\mathrm{p}<.000$ and the value for the Kaiser-Meyer-Olkin (KMO) test is 0.817. Since the large value of Bartlett's test is close to 1.00 and significant $p<.000$ as well as the KMO test which exceeds the value of .600, then the factorability can be assumed and the test can proceed. The factor loading value for DIFS items can be seen in Table 6 . In short, the DIFS items in this study have been found to form a single factor that is the differentiation of self factor. 
INTERNATIONAL JOURNAL OF ACADEMIC RESEARCH IN BUSINESS AND SOCIAL SCIENCES Vol. 10, No. 10, 2020, E-ISSN: 2222-6990 @ 2020 HRMARS

Table 6

Factor Loading Values For DIFS Items

\begin{tabular}{cc}
\hline DIFS & $\begin{array}{c}\text { Loading Value } \\
\text { (Weightage) }\end{array}$ \\
\hline C1a & 0.715 \\
C2a & 0.676 \\
C3a & 0.603 \\
C4a & 0.758 \\
C5a & 0.526 \\
C6a & 0.592 \\
C7a & 0.656 \\
C8a & 0.716 \\
C9a & 0.794 \\
C1b & 0.762 \\
C2b & 0.719 \\
C3b & 0.676 \\
C4b & 0.737 \\
C5b & 0.627 \\
C6b & 0.718 \\
C7b & 0.711 \\
C8b & 0.768 \\
\hline
\end{tabular}

Table 6 has shown that the items have acceptable factor loading values according to Hair et al., (2010), that is $>.500$. However, all item values with factor loading values in the rotated component matrix are $>.500$ (factor as large as 50\%), and > .600 (factor as large as 60\%), based on the correlation coefficient (approaching $r=1.00$ ). If it is found that the factor loading value for each item is less than $<.500$, then the particular item should be dropped or removed. However, all 17 items in The Differentiation In The Family System Scale (DIFS) test are retained.

\section{Discussion}

The findings of the study for internal consistency reliability analysis show that The Differentiation In The Family System Scale (DIFS) instrument has recorded excellent reliability coefficients. These findings are in line with DIFS internal consistency reliability results obtained by Wang (1996), Bartle, Suzanne and Gavazzi (1996); Peleg and Arnon (2013) and Likcani, Stith, Spencer, Webb and Peterson (2017).

Factor analysis on the data for the entire sample being studied shows that DIFS has a high level of construct validity. The results for this factor analysis show that seventeen DIFS items record high weightage values ranging from 0.526 to 0.794 . In short, the DIFS items in this study has been found to form a single factor, that is the self-differentiation factor between two subscales.

This study only focused on 17 items involving "interaction between mother and me" and "interaction between father and me" subscales. This approach has provided a comprehensive measure to implement the reliability of internal consistency and validity in the measurement of differentiation of self factors on the relationship of "interaction between parents and me" for the sample population of ethnic Chinese adults in Malaysia. 
INTERNATIONAL JOURNAL OF ACADEMIC RESEARCH IN BUSINESS AND SOCIAL SCIENCES Vol. 10, No. 10, 2020, E-ISSN: 2222-6990 @ 2020 HRMARS

The DIFS instrument is still considered new in Malaysia. This study is still lacking the involvement of multi-ethnic samples in Malaysia, in regards to examining the self-differentiation factors with a combination of multigenerational theories. Looking forward, it is recommended that future researchers can expand and explore the study by evaluating family resources by considering various aspects of relationships such as "interaction between me and mother", "interaction between me and father", "interaction between mother and father" and "interaction between father and mother".

Through the context of this study, the combination of DIFS instruments with multigenerational theory can be discussed and studied more deeply in the future by improving perspectives concerning educational material and conducting predictions in the field of helping professions such as psychology, counselling, psychotherapy and psychoeducation.

Furthermore, implications of the study related to DIFS instruments should also be seen as a great opportunity for researchers and practitioners in the field of family and couple therapy by focusing on "family resources" which in turn, can be used to improve the training in knowledge and skills, and even can enrich the scope of expertise in the therapeutic change process.

Finally, the findings of this study show that the DIFS instrument is suitable for local culture and environment, based on its ability to produce reliable test results. The findings of the study contribute clearly towards realising the role of family resources, the relation with cultural heritage, enriching perspectives theoretically and the expectation for more studies involving various ethnics can be conducted in Malaysia.

\section{Conclusion}

This study clearly shows that the Mandarin version of the DIFS instrument has a high level of internal consistency reliability and the Cronbach's alpha reliability coefficient obtained is in line with the results of Anderson and Sabatelli, (1992), who are the original inventors of the DIFS instrument. In other words, the reliability of the DIFS instrument can demonstrate the consistency, stability and accuracy of the scores when being tested.

In addition, differentiation of self factor formed as a result of factor analysis shows that the DIFS instrument is capable of measuring what should be measured that is to gauge the aspect of selfdifferentiation. Future researchers may even apply the DIFS instrument as a basic measurement to be used generally in bodies of knowledge, study or practice with modifications to the factors needed to meet the purpose of agencies, organisational centres and multicultural organisations. Practically, it can also be used as a diagnostic instrument for helping professions in assessing family relationships.

To conclude, the findings of this study describe the items of DIFS instrument are reliable and have a good level of validity. Therefore, this instrument is proven to be suitable for application especially within the Malaysian ethnic Chinese group and further studies need to be done for other ethnic groups in Malaysia in general. The findings of this study are expected to be useful and can act as a guide to researchers and helping profession practitioners in the future.

\section{Words of Appreciation}

The researcher would like to express gratitude to Dr. Suzana Binti Mohd Hoesni, Associate Professor Dr. Nor Ba'Yah Binti Abdul Kadir and Associate Professor Dr. Zainah Binti Ahmad Zamani for the guidance and views they have given during the process of writing this article. 
INTERNATIONAL JOURNAL OF ACADEMIC RESEARCH IN BUSINESS AND SOCIAL SCIENCES

Vol. 10, No. 10, 2020, E-ISSN: 2222-6990 @ 2020 HRMARS

\section{References}

Bowen, M. (1978). Family therapy in clinical practice. New York: Jason Aronson.

Bartle- Haring, S., \& Gavazzi, S. M. (1996). Multiple views on family data: The sample case of adolescent, maternal, and paternal perspectives on family differentiation levels. Family Process, 35(4), 457-472.

Chung, H., \& Gale, J. (2006). Comparing self-differentiation and psychological wellbeing between Korean and European American students. Contemporary Family Therapy, 28, 367-381.

Campbell, D., \& Fiske, D. (1959). Convergent and Discriminant Validation. Psychological Bulletin. (56).

Gavazzi, S. M. (1994). Advances in assessing the relationship between family differentiation and problematic functioning in adolescents. Family Therapy: The Journal of the California Graduate School of Family Psychology, 21(2).

Hellinger, B., (2014). Looking Into The Souls Of Children: The Hellinger Pedagogy In Action. Hellinger Publications Sonnleitstr. Germany.

Holman, T. B., \& Birch, P. J. (2002). Family-of-origin structures and processes and adult children's marital quality. In Premarital prediction of marital quality or breakup (pp. 79-103). Springer, Boston, MA.

Hair, J. F., Black, W. C., Babin, B. J., Anderson, R. E. (2010). Multivariate Data Analysis. Seventh ed. Prentice Hall, Englewood Cliffs.

Holman, T. B., \& Birch, P. J. I. T. B. (2001). Family-of-origin structures and processes and adult children"s marital quality. In H. A. (Eds.) (Ed.), Premarital prediction of marital quality or break up: Research, theory, and practice. New York: Plenum Press.

Kerr, M., \& Bowen, M. (1988). Family evaluation: An approach based on Bowen theory. New York, NY: Norton.

Li Meiyu. (2011). Family system differentiation, co-dependent characteristics and high school students' career decisions. Taiwan.

Likcani, A., Stith, S., Spencer, C., Webb, F., \& Peterson, F. R. (2017). Differentiation and intimate partner violence. The American Journal of Family Therapy, 45(5), 235-249.

Lampis, J. (2015). Does partners' differentiation of self predict dyadic adjustment?. Journal of Family Therapy, 38(3), 303-318.

Lampis, J., Cataudella, S., Agus, M., Busonera, A., \& Skowron, E. A. (2018). Differentiation of self and dyadic adjustment in couple relationships: A dyadic analysis using the actor-partner interdependence model. Family process, 58(3), 698-715.

Lee, H., \& Sabatelli, R. M. (2018). Measurement Invariance of the Differentiation of Family System Scale for Koreans and Americans. Journal of Comparative Family Studies, 49(3), 379-397.

Muraru, A. A., \& Turliuc, M. N. (2013). Predictors of Marital Adjustment: Are There Any Differences Between Women and Men?. Europe's Journal of Psychology, 9(3), 427-442.

Muraru, A. A., \& Turliuc, M. N. (2012). Family-of-origin, romantic attachment, and marital adjustment: a path analysis model. Procedia-Social and Behavioral Sciences, 33, 90-94.

Norfaezah, M. K. (2016). Kesan kefungsian keluarga asal, pembezaan kendiri dan sikap terhadap peranan gender ke atas kualiti perkahwinan. Latihan IImiah. Universiti Malaya. Kuala Lumpur.

Peleg, O., \&Arnon, T. (2013).Are differentiation levels associated with schizophrenia?. Deviant Behavior, 34(4), 321-338.

Peleg, O., \& Messerschmidt-Grandi, C. (2018). Differentiation of self and trait anxiety: A cross-cultural perspective. International Journal of Psychology, 54(6), 816-827. 
INTERNATIONAL JOURNAL OF ACADEMIC RESEARCH IN BUSINESS AND SOCIAL SCIENCES

Vol. 10, No. 10, 2020, E-ISSN: 2222-6990 @ 2020 HRMARS

Reber, A. S. (1985). The Penguin Dictionary of Psychology, Penguin Books, Haemondsworth, UK.

Stephen, A. A., \& Sabatelli, R. M. (1992). The Differentiation in The Family System Scale (DIFS). The American Journal Of Family Therapy. 20 (1): 77-89.

Sabatelli, R. M., \& Bartle-Haring, S. (2003). Family-of-origin experiences and adjustment in married couples. Journal of Marriage and Family, 65(1), 159-169.

Timm, T. M., \& Keiley, M. K. (2011). The effects of differentiation of self, adult attachment, and sexual communication on sexual and marital satisfaction: A path analysis. Journal of Sex \& Marital Therapy, 37(3): 206-223.

Vierra, A., \& Pollock, J. (1992). Reading Education Research. Scottsdale: Gorsuch Sewishirch.

Wiersma, W. (2000). Research In Education: An Introduction. Boston: Allyn and Bacon.

Wang, T. W. (1996). The relationship between family system differentiation and psychosocial development among college students. Master Thesis, National Chunghua University of Education, Chunghua, Taiwan.

Zhou, DingWen. (2020). Family System Arrangement: Core Principles and Practices. Mind Workshop Cultural Enterprise Co., Ltd. Taiwan. 
INTERNATIONAL JOURNAL OF ACADEMIC RESEARCH IN BUSINESS AND SOCIAL SCIENCES

Vol. 10 , No. 10, 2020, E-ISSN: 2222-6990 @ 2020 HRMARS

\section{Appendix 1}

\section{SECTION A FAMILY RELATIONSHIP ENGLISH VERSION}

Instructions: Please use YOUR OWN OPINION in evaluating "Interaction in the Relationship Between Myself and My Parents". The column below is for "Interaction in the Relationship Between Yourself And Your Mother". Please indicate the response in the space provided below.

1. Infrequent

2. Almost Infrequent

3. Sometimes

4. Almost Frequent

5. Frequent

\begin{tabular}{|c|c|}
\hline $\begin{array}{c}\text { Interaction In The Relationship Between My Mother } \\
\text { And Myself }\end{array}$ & $\begin{array}{c}\text { Interaction In The } \\
\text { Relationship Between } \\
\text { Your Mother And Yourself }\end{array}$ \\
\hline $\begin{array}{l}\text { 1. ....will respect (my) point of view even (our) } \\
\text { points of view is different. }\end{array}$ & \\
\hline 2. ....treat (my) feelings as nothing. & \\
\hline 3. ... will respect (my) privacy. & \\
\hline 4. ... accept my feelings in an understanding way. & \\
\hline 5. ... there is a lack of concern to (my) feelings. & \\
\hline $\begin{array}{l}\text { 6. ... will encourage (me) to express (my) inner } \\
\text { positive or negative feelings. }\end{array}$ & \\
\hline $\begin{array}{l}\text { 7. ... treat (my) point of view and opinion as } \\
\text { nothing. }\end{array}$ & \\
\hline $\begin{array}{l}\text { 8. ... shows understanding when (I) do not want to } \\
\text { share (my) feelings. }\end{array}$ & \\
\hline $\begin{array}{l}\text { 9. ...able to tolerate (me) to defend (my) own point } \\
\text { of view/idea. }\end{array}$ & \\
\hline
\end{tabular}


INTERNATIONAL JOURNAL OF ACADEMIC RESEARCH IN BUSINESS AND SOCIAL SCIENCES Vol. 10, No. 10, 2020, E-ISSN: $2222-6990$ @ 2020 HRMARS

\section{Appendix 2}

\section{CFA (Confirmatory Factor Analysis)} Interaction Between Parents And Me

KMO and Bartlett's Test

\begin{tabular}{|c|c|c|}
\hline $\begin{array}{l}\text { Kaiser-Meyer-Olk } \\
\text { Adequacy. }\end{array}$ & sure of Sampling & .817 \\
\hline & Approx. Chi-Square & 4377.482 \\
\hline Sphericity & $d f$ & 231 \\
\hline & Sig. & .000 \\
\hline
\end{tabular}

\begin{tabular}{l|r|r|}
\multicolumn{2}{|c|}{ Rotated Component Matrix ${ }^{\mathrm{a}}$} \\
\hline & \multicolumn{2}{|c|}{ Component } \\
\cline { 2 - 3 } & Father & \multicolumn{1}{c|}{ Mother } \\
\hline c1a & & .715 \\
c2a & & .676 \\
c3a &. & .603 \\
c5a &. & .758 \\
c7a & & .526 \\
c8a & & .592 \\
c9a & & .656 \\
c10a & & .716 \\
c11a & & .794 \\
c1b & .762 & \\
c2b & .719 & \\
c3b & .676 & \\
c5bac & .737 & \\
c8bw & .627 & \\
c9b & .718 & \\
c10b & .711 & \\
c11b & .768 & \\
\hline
\end{tabular}

Extraction Method: Principal

Component Analysis.

Rotation Method: Varimax with

Kaiser Normalization. ${ }^{a}$

a. Rotation converged in 3 iterations. 